\title{
Restructure Expectation and the Mug's Games of Capital Market
}

\author{
Wenlong Deng, Yetaotao Qiu \\ Management School, Jinan University, Guangzhou, China \\ Email: deng1021443713@163.com
}

Received 24 February 2015; accepted 11 March 2015; published 17 March 2015

Copyright (C) 2015 by authors and Scientific Research Publishing Inc.

This work is licensed under the Creative Commons Attribution International License (CC BY). http://creativecommons.org/licenses/by/4.0/

(c) (i) Open Access

\begin{abstract}
At the end of 2014, wars of protecting shell resource broke out in Chinese A-share market. Based on the case of financial fraud of WanFu Biotechnology, we present and explain the trade abnormality existing in the capital market from restructure perspective. By virtue of analyzing the case of WanFu Biotechnology, we reveal the loopholes in the capital system, and finally put forward some corresponding policy suggestions for policy makers.
\end{abstract}

\section{Keywords}

\section{Restructure Expectation, WanFu Biotechnology, Capital Market Supervision}

\section{Introduction}

China's security market is still in its infancy period, there were lots of financial fraud and fraud-listed cases in this fledgling capital market. Yin Guangsha and the Lantian shares, the first blue chip and the first agricultural stock respectively, caused serious cost to investors. Besides, the recent financial fraud cases, like Green Earth, Hirisum Technology and the notorious WanFu Biotechnology greatly disturbed China's capital market order. For the sake of the healthy development of security market, the regulators introduced a series of rules. The CSRC (China Securities Regulatory Commission) released "The Regulations About Material Assets Restructure of The Listing Corporation" and "The Revision Decision About The Regulations of Listing Corporations Acquisition" in Oct. 2014. At the same time, the claimed harshest delisting system was officially launched in 16th Nov. 2014, which banned stock listing through shell buying in GEM (Growth Enterprise Market). Public companies incurring three consecutive annual losses in GEM would be delisted directly, without the ST transition period. These measures highlight the purpose of regulators of reshape Chinese capital market.

Facing new delisting system and two consecutive annual losses in 2012 and 2013, WanFu Biotechnology took the risk of delisting. In the third quarter of 2014, it still suffered net loss of 27.18 millions. Which means that 
WanFu Biotechnology must achieve full-year profit, otherwise it is likely to be suspended or terminated after it discloses the 2014 annual report.

The bad news about WanFu Biotechnology kept coming out, but investors were crazy about buying the stock and thus pushing the stock price to a rocket-high level. Figure 1 shows that stock price kept rising after resumption, and the highest price reached 17.8¥ per share (28th Jan. 2015). Besides, low trading volume gave no hint of any capital flight after the bad news release. The market value reached to 2200 million Yuan from the bottom of 75.71 million Yuan. The driven factor behind the share price climbing was a possible restructure of WanFu Biotechnology, and it was the market expectation that made investors ignore the huge risk of being suspended.

Assets restructure refers to asset purchases, asset sale and asset swap conducted in different enterprises or the same enterprises, to improve the return on assets and increase the value of the enterprise. But there is no absolute evidence to confirm the relationship between assets restructure and performance improvement. Healy, Palepu and Ruback (1992) [1] concluded that firm performance was enhanced after the acquisition, as the acquisition could improve its internal resource allocation. But Agrawal, Jaffe and Mandelker (1992) [2] hold different opinions, according to their research, asset restructure doesn't exert significant positive effects on company performance, or even negative effects. Liao Li and Zhu Zhengqin (2004) [3] analyzed the performance of 71 listed companies that took corporate restructure, based on their research, assets restructure improved the profitability, but couldn’t enhance corporate cash flow management, financial conservatism and operating capacity.

\section{Analysis of Financial Condition}

\subsection{Analysis of Related Interests}

As the majority shareholder of WanFu Biotechnology, the Gong couple secured debt financing of 140 million Yuan from Taoyuan Xianghui Agricultural Investment Co. Ltd. and signed a debt-transfer agreement with Ningbo Yong Tao Investment Co. Ltd. in August and September, 2013. Ningbo Yong Tao repaid the debts of 60 million Yuan for Mr. and Mrs. Gong to the Zhongyuan Trust. In January 20, 2014, Taojiang court ruled that Gong Yongfu and Yang Ronghua transferred 25.08 and 10 million restricted shares to Taoyuan Xianghui Agricultural Investment Co. Ltd. respectively at the price of 3.99 Yuan to clear off the debts. Ningbo Yong Tao received 15.03 million restricted shares for its creditor of 60 million Yuan.

Founded on August 27th 2013, Taoyuan Xianghui registered the capital of 50 million. Apart from involving in the debt crisis of Gong couple, the company has not started any business activity. Thus, the company could not lend 140 million Yuan of debt considering its own financial condition. The debts between Taoyuan Xianghui and Mr. and Mrs. Gong have high likelihood of being carefully planned for the shell protection.

Judging from the interests of relevant parties involved, and considering the number of equity transfer and the amount of loan, Taoyuan Xianghui is undoubtedly the biggest winner. Figure 2 describes the change of ownership structure. According to the shares (16.78 Yuan per share) on January 23th, 2015, 26.18\% of stock shares held by Taoyuan Xianghui were worth of more than 588 million Yuan. Meanwhile, Taoyuan Xianghui gained the control right of WanFu Biotechnology at the price of 225 million Yuan in order to pay 85 million Yuan to

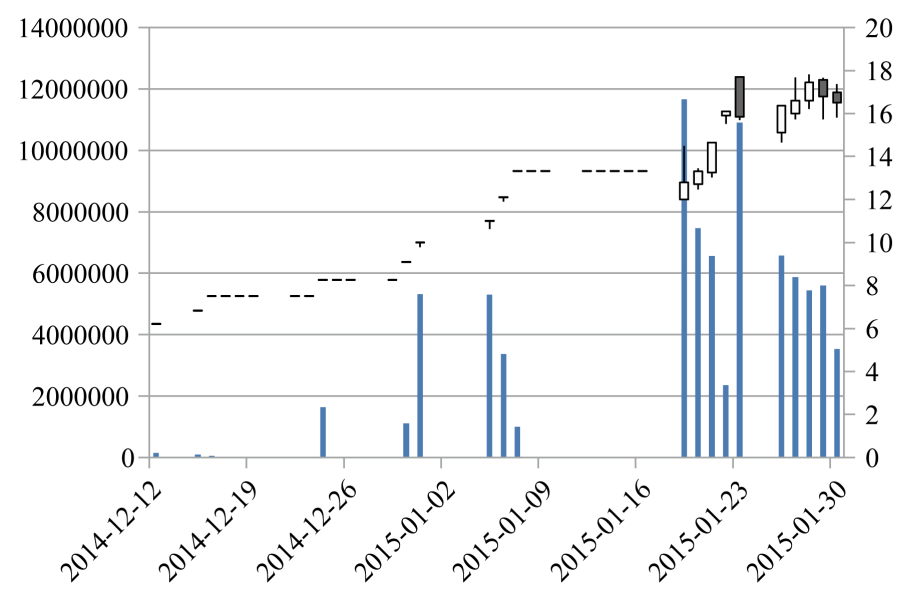

Volume

the opening price $(¥)$

highest price (¥)

lowest price $(¥)$

The closing price (¥)

Figure 1. Stock price and volume of WanFu Biotechnology. 
Mr. and Mrs. Gong; The 11.22\% of stock share of WanFu Biotechnology worth 252 million Yuan of market value, more than three times of the loans. Through debts payment by stock and judicial transfer, Gong Yongfu, and Yang Ronghua can not only save the shell resource of WanFu Biotechnology, and the stock market value was increasing as well.

\subsection{Analysis of Company's Financial and Operating Status}

WanFu Biotechnology suffered from really bad financial performance as the result of fraud punishment. Its operating income and net profit level after deducting non-recurring profit and loss dropped year by year. From Figure 3 we can see that In 2013, the net profit after deducting non-recurring gains and losses fell to its lowest point of -150 million Yuan. The net loss of three quarters in 2014 was 27.1863 million Yuan. If the full year losses cannot be reversed in the fourth quarter, the company is likely to face the risk of being delisted.

Reviewing past cases, we find a series of shell protection measures for the listed companies in our country. For example, fighting for the governmental subsidies and debt relief (* ST Chang Jiu, * ST Dahua B), or the restructure of assets (Yihua * ST and * ST East Force), etc. WanFu Biotechnology was also trying to reverse losses in 2014 by similar means. On the one hand, the company was going to increase the net profit to 29 million Yuan through the disposal of idle assets and transfer the $100 \%$ stock of two wholly owned subsidiaries with a total of 87.9824 million Yuan (the case is still in the plan phase of the board of directors); On the other hand, WanFu Biotechnology obtained 16 million Yuan of payment from the people's government of Taoyuan county

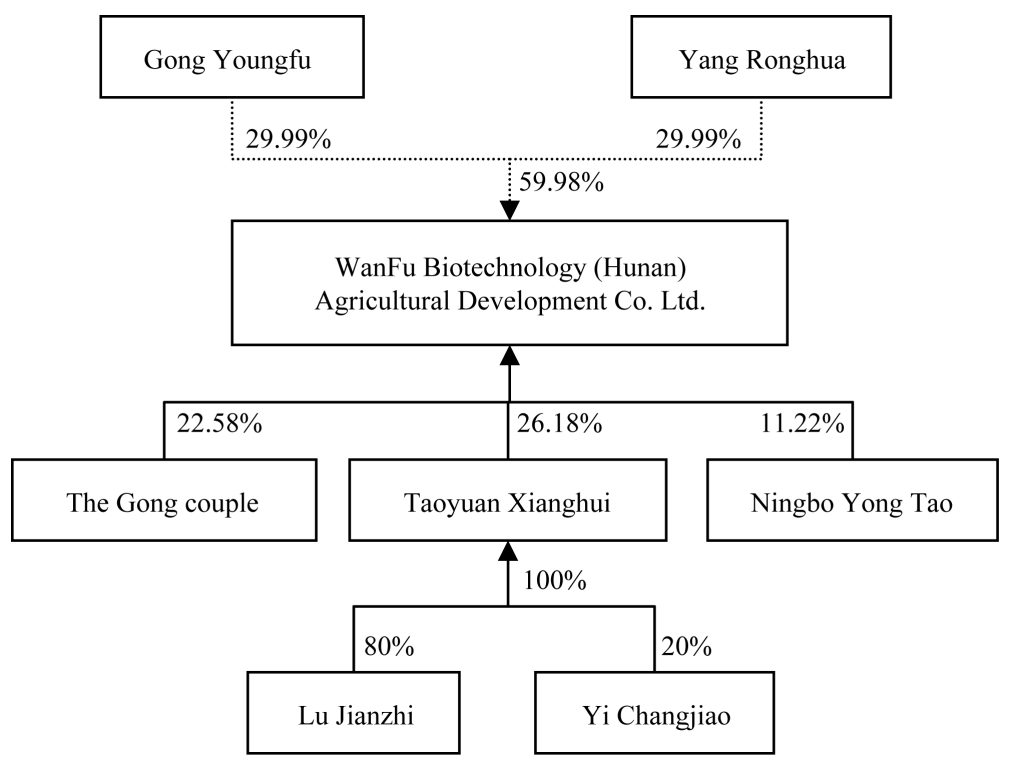

Figure 2. Equity modification of WanFu Biotechnology.

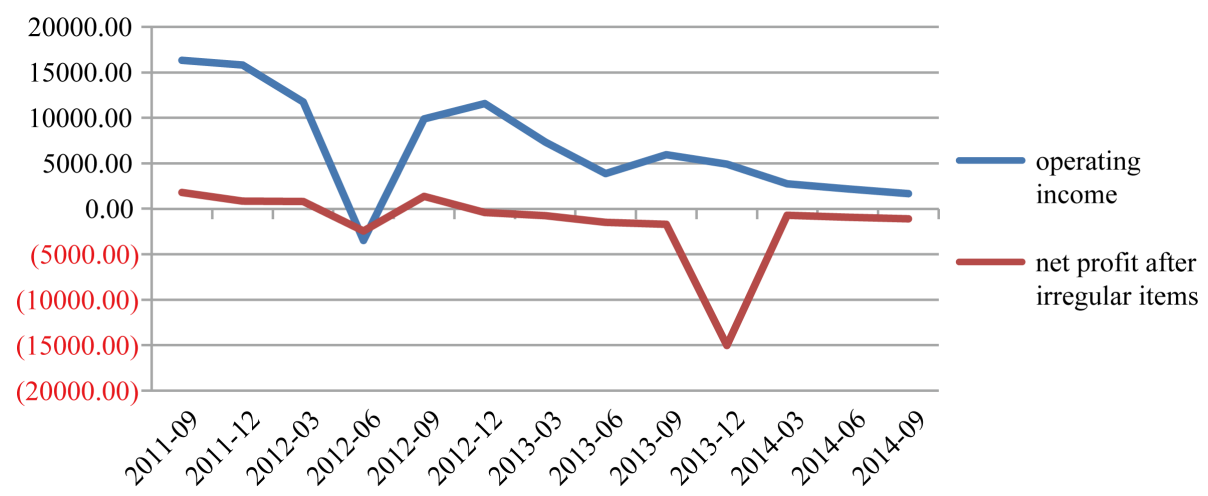

Figure 3. Operating performance of WanFu Biotechnology. 
on December 25th, 2014 and gained 2.1025 million Yuan debt relief on 26th. According to current GEM rules, the CSRC will measure the net loss of listed companies based on the audited net profit of the same year and will also take government subsidies, and earnings from non-current assets disposal into account. Thus, WanFu Biotechnology had 47.1025 million Yuan of audit net profit through these non-recurring gains. If the fourth quarter of 2014 incurs small amount of losses, profit of the year before last can be achieved.

Judging from Table 1 as below, since it was listed in 2009, the asset-liability ratio of Wan Fu Biotechnology remains low and the liquidity ratio decreased from 2.38 in 2011 to 1.14 in the third quarter of 2014, which explains its high solvency risk; at the same time, the financial indexes of ROA, ROE and net sales interest rate indicate that the enterprise's profitability gradually deteriorated. Also, the rising financial expense to revenue ratio shows that the firm lacks the cost management ability, which shows that the operating income ratio of WanFu Biotechnology is not ideal. The cash flow generated by net business activities per share was 0.06 Yuan, which reflects the enterprise's weak ability of paying dividends and capital spending; judging from declining trend of enterprise operating capacity index, the assets of WanFu Biotechnology cannot be fully utilized and managed.

\section{The Trade Heteromorphism under Risk of Suspension Listing}

As a stock listed by financial fraud, WanFu had loss for two consecutive years and the third quarter of 2014. Although the company announced that it would achieve profit through such measures as cost control, restructure of related assets, and seeking for support, the financial condition of WanFu Biotechnology is still pessimistic; What is more, the company was publicly condemned by the Shenzhen stock exchange in 2012 and 2013. According to the "GEM stock listing rules" regulation, if a listed company was publicly condemned for three times in 36 months it would be terminated.

WanFu Biotechnology has received risk warning announcement 6 times in a row since its resumption, but investors' irrationality led to the company's nine consecutive days of harden board. As of January 23, 2015, the share price rose by $197 \%$ and the turnover rate was as high as $34.3 \%$. If the stock price slump reflects the market effectiveness, then the consecutive price limit imposed by CSCR since resumption indicated that investors did not have pessimistic outlook on the stock. Based on the above analysis, restructuring of WanFu Biotechnology is more like a mug's game.

Table 1. Operating performance of WanFu Biotechnology.

\begin{tabular}{|c|c|c|c|c|c|}
\hline Financial Analysis & Financial Index & 2011 & 2012 & 2013 & 2014 \\
\hline \multirow[b]{2}{*}{ Debt paying ability } & Asset-liability ratio & 36.37 & 47.06 & 36.49 & 33.60 \\
\hline & Current ratio & 2.38 & 1.43 & 1.61 & 1.14 \\
\hline \multirow{7}{*}{ Profit quality } & ROE & 8.99 & $(0.68)$ & $(8.40)$ & $(5.86)$ \\
\hline & ROA & 10.69 & 1.59 & $(3.35)$ & $(3.20)$ \\
\hline & Sales net profit rate & 10.89 & $(1.15)$ & $(22.06)$ & (31.97) \\
\hline & Management expenses/operating income & 5.28 & 7.30 & 13.70 & 25.64 \\
\hline & Basic EPS & 1.12 & $(0.03)$ & $(0.28)$ & $(0.12)$ \\
\hline & Net asset per share & 10.00 & 3.64 & 3.35 & 2.11 \\
\hline & Net cash flow of business operations per share & 0.50 & 0.21 & 0.62 & 0.06 \\
\hline \multirow{4}{*}{ Operation capacity } & Inventory turnover & 1.97 & 1.05 & 0.94 & 1.04 \\
\hline & Accounts receivable turnover & 24.54 & 11.10 & 12.99 & 5.34 \\
\hline & Turnover rate of the current assets & 1.02 & 0.44 & 0.42 & 0.32 \\
\hline & Turnover rate of total assets & 0.71 & 0.30 & 0.22 & 0.11 \\
\hline
\end{tabular}

Note: the financial data of 2014 up to the third quarter, because there hasn't been full financial disclosure. 
The new reversion of "measures to the administration of material assets restructure of the listed company" regulates that backdoor listings shares need to meet the same requirement with IPO and meanwhile, the GEM-listed companies are not allowed to conduct backdoor listings. However, regulators consider that backdoor listings should fulfill two conditions at the same time: one is the change of real controller of listed companies; the other one is that the total assets bought from purchaser and the associated partners account for more than $100 \%$ of its own assets in the year before changing actual controller.

After avoiding the delisting policy of "the break off of new and old deal”, the company announced the policy of paying debts by stocks and changed the actual controller through judicial transfer. In the future, the company will improve its business performance through assets injection and won't need to obey the strict delisting policy in the history. Then the capital market considers that the suspension crisis should be temporarily eliminated. If the profit needs to be achieved in order to avoid the suspension of listing, other assets need to be injected into the company. Although the announcement made it clear that Taoyuan Xianghui has not set up a major adjustment plan to change the business scope of WanFu Biotechnology in 12 months. However, investors still have strong hope for the company's reconstruction.

Asset restructure is an effective way to adapt to the financial environment and improve the efficiency of using resources (Chen Xinyuan, Zhang Tianyu, 1999) [4]. According to some domestic research, asset restructuring of listed companies can be divided into four categories: expansion; contraction; controlling-power transferring; as well as strategic shift. As the control right of WanFu Biotechnology is changed, it belongs to the controlling power transferring. Li Shanmin and Li Heng (2003) [5] conducted research in 2000 through PCA method (principal component analysis), and found that only the performance of the contracted firms improved significantly in the following 2 years, the other types of assets restructuring has not made significant changes.

Gao Yongqiang and Xiong Wei (2013) [6] studied simple firms that transferred control right, and found that these companies could not maintain its financial performance, let alone make any improvements. By studying 78 listed companies which transferred controlling right in 2000, Wang Xuguo (2004) [7] found that the comprehensive performance scores in the following 4 years are lower than that before the transfer, most of the company's performance after control transfer is worsening! The foreign literatures about asset restructure and operating performance did not reach a unified conclusion. Jensen and Ruback (1983) [8] argued that corporate takeovers generate positive gains, which will benefit target firm shareholders, and that bidding firm shareholders also made earnings in this trade. The gains created by corporate takeovers do not appear to come from the extension of market power and the rights to manage corporate resources. Although the acquisition of Taoyuan Xianghui signaled positively to capital market and prompted investors to have strong expectation of asset restructuring, the company still faced a business performance upgrading puzzle, namely, whether WanFu Biotechnology 's operating performance can be improved after the asset restructure is completed.

\section{Conclusions}

This paper mainly discussed the trade abnormality of WanFu Biotechnology after resumption, and revealed the loopholes in the capital system, finally put forward some corresponding policy suggestions for policy makers. We found that investors bought shares of WanFu Biotechnology because of restructure expectation, under the background of bad operating and financial situation, the crazy speculation is more like mugs' games.

What make our research different is that we analyzed the phenomenon in a restructure expectation perspective, and reveal loopholes in the regulation of securities market, for the sake of healthy development of securities market, the supervision institutions need to put forward more effective measures. The limitation of this paper is that we only take the firm level features into consideration, but stock price is also affected by factors such as capital market volatility and policy change; it's a preliminary study on trade abnormality, and it needs to be improved by further analysis.

\section{Policy Suggestions}

As the first gem-listed fraud case, WanFu case greatly shocked the capital market and ended with the successful change of actual controller. Although the company had issued several delisting risk warning notices and abnormal stock price fluctuations for verification, the shares soared as usual. The irrational enthusiasm of market stirred and the risk continued to accumulate so that the mug's game was ultimately unsustainable. The financial fraud of WanFu Biotechnology brought huge losses to the investors, broke the rule of "survival of the fittest" of 
the capital market, and hindered the healthy development of security market in China. Therefore, this paper put forward the following policies, suggestions and measures:

- To further improve "the supervision of material assets restructure of listed companies" and the delisting system, the market positioning and regulatory tendency, which focus on financing and listing but neglect returns and delisting, should be changed. For the convenience of practical operation, Delisting rules adopted the principle of "breaking down old and new rules". However, this makes the earlier listed companies benefit from the administrative punishment, and is almost in a disguised form to encourage listed companies violate the rules as soon as possible. WanFu Biotechnology cannot continue listing and change the company's controlling power through market transaction. However, new delisting policy allows judicial transferring and provides a good shelter for other listed companies which seek for shell protection to avoid monitoring. Therefore, it seems that the security market supervision still needs to be further enhanced.

- To strengthen the external supervision, audit rotation system needs to be carried out in order to strengthen the punishment of financial fraud in listed companies. In the Enron scandal, the fines for intermediary JP Morgan and City Group were up to $\$ 300$ million. The Arthur Andersen went bankrupt, and company executives were sentenced to 100 years in prison, with nearly $\$ 200$ million fine penalty. In comparison, the WanFu Biotechnology disclosed false income and profit number, raising 425 million Yuan in the capital market. However, the company was only fined $\$ 8.5$ million and the former chairman of the board of directors was only sentenced to three and a half years. The Ping An Securities was just confiscated underwriting income and fined with twice of the penalty. The intermediary, Mileage Limited Liability Accounting Firm of Hunan Changde branch offices was only fined 660,000 Yuan. So the light penalties clearly are not sufficient to deter current frequent unlawful act.

- Introducing the trading mechanism of regulators and the regulated. This system does not aim to reduce penalties for those violated regulations but aim to conduct appropriate sanctions to those fraud companies when financial fraud cause losses to stakeholders. The trading system of regulators and the regulated is introduced in overseas market and the formal legal term is "law enforcement reconciliation". Its significance lies in the fact that securities violations are often highly specialized and regulators may not be able to grasp the sufficient evidence. There are two options: one is to stick to the inspection to the end, and the key evidence might not be found in the end. As consequences, no measure can be taken to the suspect; another option is to negotiate with the suspect, and seal a deal through compromise from two parties. The CSRC also provides the flexibility to propose some requirements to the suspect and these requirements may not only have the simple nature of punishment, but also have other important functions of education and compensation (such as the compensation fund established in the financial fraud of WanFu Biotechnology). However, the establishment of the system should not only draw lessons from international experience, but combine with China's unique conditions. If this act is well conducted, the enforcement efficiency of the securities and futures commission can be enhanced, or law enforcement of compromise might be easily abused and even lead to corruption. As a consequence, the fairness image of the CSRC will be damaged.

- More attention should be paid to the internal risk prevention. Through dispersing equity, introducing institutional investors, utilizing professional management caliber, the quality of listed companies' earnings can be improved and restriction and supervision on large shareholder can be achieved; At the same time, the audit committee is established and the independence of the audit committee and professionalism ought to be further improved in order to reduce the illegal act of listed companies.

\section{References}

[1] Healy, P.M., Palepu, K.U. and Ruback, R.S. (1992) Does Corporate Performance Improve after Mergers? Journal of Financial Economics, 2, 135-175. http://dx.doi.org/10.1016/0304-405X(92)90002-F

[2] Agrawal, A., Jaffe, J.F. and Mandelker, G.N. (1992) The Post-Merger Performance of Acquiring Firms: A Re-Examination of an Anomaly. Journal of Finance, 4, 1605-1621. http://dx.doi.org/10.1111/j.1540-6261.1992.tb04674.X

[3] Liao, L. and Zhu, Z.Q. (2004) Study on the Performance Improvement after Assets Restructure of Listed Companies in China. China Industrial Economy, 10, 97-104.

[4] Chen, X.Y. and Zhang, T.Y. (1999) Market Reaction of Asset Restructure. Economic Research Journal, 9, 47-55.

[5] Li, S.M. and Li, H. (2003) Study on the Assets Restructure Performance of Listed Companies in China. Journal of Management World, 11, 126-134. 
[6] Gao, Y.Q., Xiong, W. and Yang, B. (2013) Study on the Impact of Corporate Control Transfer, Asset Restructure and CEO Turnover on Enterprises’ Performance. Journal of Contemporary Economy \& Management, 2, 24-32.

[7] Wang, X.G. (2004) Empirical Analysis and Explanation about Merger Performance of Listed Companies in China. Special Zone Economy, 11, 60-62.

[8] Jensen, M.C. and Ruback, R.S. (1983) The Market for Corporate Control. Journal of Financial Economics, 83, 5-50. http://dx.doi.org/10.1016/0304-405X(83)90004-1 